\title{
KARAKTERISTIK, MOTIVASI DAN KEPUASAN WISATAWAN ASAL INDONESIA YANG BERWISATA KE VIETNAM
}

\author{
Kristina Valentina Br Siregar ${ }^{1}$, IGPB. Sasrawan Mananda ${ }^{2}$, Putu Agus Wikanatha Sagita ${ }^{3}$ \\ Email: cristinaayu54@gmail.com¹,gusmananda@unud.ac.id², aguswika@unud.ac.id ${ }^{3}$ \\ ${ }^{1,2,3}$ Program Studi Industri Perjalanan Wisata, Fakultas Pariwisata, Universitas Udayana
}

\begin{abstract}
Vietnam has the inbound tourism growth in ASEAN within $20 \%$ and also Indonesian tourist visits to Vietnam increase every year. This study aims to identify the characteristics, motivation and satisfaction of Indonesian tourists who traveled to Vietnam and expected to be used as a consideration by tourism expertise, especially outbound tourism activities in order to fulfil their needs and expectations. The sample of this research is Indonesian tourists who have visited Vietnam. The sampling technique used purposive sampling method towards 100 respondents. Data collection techniques were conducted in several ways, such as: observation, questionnaires, literature study, and documentation. Data analysis was performed using quantitative descriptive analysis techniques. The results showed that the motivation of influencing most of Indonesian tourists who traveled to Vietnam was cultural motivation with an average value of 4.45 (strongly agree) and the indicator that had the highest value was seeing and knowing the culture in Vietnam with an average value. 4.53. In addition, in terms of the level of tourist satisfaction, it shows that among the four main components of tourism which consist of attraction, amenities, accessibility, and ancillary (4A), the attraction component has the highest satisfaction score of $87,1 \%$ (Very Satisfied) and the indicator with the highest score is Vietnam has a good and attractive natural tourism with total score of $88,8 \%$ (Very Satisfied). Overall, the satisfaction level of Indonesian tourists visiting Vietnam has score 80,7\% (Satisfied), which means that Indonesian tourists visiting Vietnam are satisfied with attractions, amenities, accessibility, and ancillary in Vietnam.
\end{abstract}

Abstrak: Vietnam memiliki pertumbuhan inbound tourism tertinggi di ASEAN sebesar 20\%. Kunjungan wisatawan Indonesia ke Vietnam meningkat setiap tahunnya. Penelitian ini bertujuan untuk mengetahui karakteristik, motivasi dan kepuasan wisatawan Indonesia yang berwisata ke Vietnam dan diharapkan dapat digunakan sebagai pertimbangan oleh para pelaku industri pariwisata khususnya outbound tourism dalam memenuhi kebutuhan wisatawan Indonesia tersebut. Sampel dari penelitian ini yaitu wisatawan Indonesia yang pernah mengunjungi Vietnam. Teknik penentuan sampel menggunakan non probability sampling yaitu dengan metode purposive sampling pada 100 orang responden. Teknik pengumpulan data dilakukan dengan beberapa cara, diantaranya: observasi, kuesioner, studi kepustakaan, dan dokumentasi. Analisis data dilakukan dengan teknik analisis deskriptif kuantitatif. Hasil penelitian menunjukkan bahwa motivasi yang paling mempengaruhi wisatawan Indonesia yang berwisata ke Vietnam yaitu cultural motivation dengan nilai rata-rata 4,45 (sangat setuju) dan indikator yang memiliki nilai paling tinggi yaitu melihat dan mengetahui kebudayaan yang ada di Vietnam dengan nilai rata-rata 4,53. Selain itu, ditinjau dari tingkat kepuasan wisatawan menunjukkan bahwa diantara empat komponen utama pariwisata yang terdiri dari attraction, amenities, accessibility, dan ancillary (4A), komponen attraction mempunyai nilai tingkat kepuasan tertinggi sebesar $87,1 \%$ (Sangat Puas) dan indikator dengan nilai tertinggi yaitu Vietnam memiliki wisata alam yang baik dan menarik dengan tingkat kepuasan sebesar 88,8\% (Sangat Puas). Secara keseluruhan, tingkat kepuasan wisatawan Indonesia yang berwisata ke Vietnam memiliki nilai 80,7\% (Puas) yang berarti wisatawan Indonesia yang berwisata ke Vietnam puas terhadap attraction (atraksi wisata), amenities (fasilitas), accessibility (aksesibilitas), dan ancillary (pelayanan tambahan) yang ada di Vietnam.

Keywords: motivation, satisfaction, indonesian tourist, vietnam. 


\section{PENDAHULUAN}

Vietnam menjadi negara dengan pertumbuhan pariwisata terbesar di kawasan Asia Tenggara dengan pertumbuhan sebesar 17,98\% pada Tahun 2018. Hal ini mendasari peneliti untuk meneliti kepariwisataan Vietnam. Vietnam adalah negara terpadat nomor 13 di dunia. Vietnam termasuk di dalam grup ekonomi "Next Eleven" atau sering disebut N-11 yang terdiri dari 11 negara (Bangladesh, Vietnam, Filipina, Indonesia, Iran, Korea Selatan, Meksiko, Mesir, Nigeria, Pakistan, Turki). Negara-negara ini dianggap memiliki masa depan yang menjanjikan untuk investasi dan pertumbuhannya. Pada Tahun 2014, Vietnam memiliki jumlah wisatawan mancanegara sebanyak 7,8 juta orang. Kemudian pada tahun 2015, jumlahnya meningkat sekitar 100.000 wisatawan lebih banyak daripada tahun sebelumnya. Pada tahun 2016, Vietnam mengalami tingkat pertumbuhan yang drastis yakni sebesar $26 \%$, dan kembali meningkat pada Tahun 2017 hingga mencapai $29 \%$. Kunjungan wisatawan mancanegara ke Vietnam semakin meningkat dan mencapai angka 15,4 juta wisatawan pada Tahun 2018. fakta ini memperlihatkan bahwa Vietnam mulai menjadi sorotan dunia untuk di jadikan tujuan berwisata. Menurut Tourism Highlight 2018, Vietnam menjadi negara dengan pertumbuhan terbesar dibandingan dengan negara lain yang ada di Asia Tenggara Menurut Travellers Choice 2019 yang di selenggarakan oleh Trip Advisor, Vietnam merupakan tujuan wisata popular dimana empat dari destinasi wisata yang ada di Vietnam termasuk kedalam 25 Destinasi Terpopuler Asia diantaranya, Hanoi, Ho Chi Minh City, Hoi An, dan Da Nang.

Wisatawan Indonesia juga turut serta pada peningkatan jumlah kunjungan wisatawan Vietnam secara pesat. Hal tersebut dapat dibuktikan dengan jumlah kunjungan wisatawan Indonesia yang melakukan kegiatan pariwisata ke Vietnam mengalami peningkatan setiap tahunnya. Wisatawan Indonesia yang berwisata ke Vietnam pada tahun 2014 berjumlah 68.000 wisatawan, namun mengalami penurunan di tahun 2015 yang hanya mencapai 62.000 wisatawan, pada Tahun 2016 jumlah wisatawan Indonesia kembali mengalami kenaikan dengan tingkat persentase pertumbuhan pada tahun 2016 sebesar 11,9\%.
Tingkat pertumbuhan tertinggi terjadi pada tahun 2017 dengan persentase sebesar 16,3\%. Hingga pada tahun 2018, wisatawan Indonesia yang berwisata ke Vietnam mencapai 87.000 wisatawan. Hal ini menunjukkan bahwa minat wisatawan Indonesia untuk berkunjung ke Vietnam sangat tinggi. Meningkatnya jumlah kunjungan wisatawan Indonesia yang berwisata ke Vietnam bukan hanya disebabkan oleh motivasi atau ketertarikan masyarakat Indonesia terhadap atraksi wisata yang ada di Vietnam, namun juga karena adanya kepuasan setelah berkunjung dan merekomendasikan pengalaman berwisata ke Vietnam kepada teman, kerabat dan orang lain di sekitarnya. Kepuasan wisatawan adalah sikap wisatawan secara keseluruhan terhadap penyedia layanan, atau reaksi emosional untuk perbedaan antara apa yang wisatawan harapkan dan apa yang mereka terima, mengenai pemenuhan beberapa kebutuhan, tujuan atau keinginan (Henenark dan Albinson dalam Emmanuel, 2015). Hal ini menjadi menarik bagi peneliti untuk mengetahui karakteristik, motivasi, dan kepuasan wisatawan Indonesia yang berwisata ke Vietnam, dimana pariwisata Vietnam sedang menjadi sorotan dunia saat ini.

\section{METODE}

Penelitian ini bertujuan untuk meneliti mengenai karakteristik, motivasi, dan kepuasan wisatawan Indonesia yang berwisata ke Vietnam. Karakteristik wisatawan dibagi atas dua sub variabel, yaitu trip descriptor dan tourist descriptor. Sub variabel trip descriptor terdiri atas: lama perjalanan, jenis akomodasi, jenis transportasi, pengorganisasian perjalanan, besar pengeluaran, jumlah kunjungan, dan sumber informasi. Sementara itu, sub variabel tourist descriptor terdiri atas: jenis kelamin, umur, pekerjaan, dan daerah asal. Motivasi wisatawan yang berwisata ke Vietnam ditinjau berdasarkan empat motivasi wisatawan (MacIntos, 2002) yang terdiri atas: physical motivation, cultural motivation, interpersonal motivation, serta status and prestige motivation. Kepuasan wisatawan yang berwisata ditinjau berdasarkan empat komponen utama pariwisata (Cooper, 1993) yang terdiri atas: attraction, amenities, accessibility, dan ancillary service.

Pengumpulan data dilakukan dengan empat cara, yaitu observasi, kuesioner, 
dokumentasi, dan studi pustaka. Teknik penentuan sampel dengan purposive sampling yaitu penentuan sampel dengan pertimbangan tertentu dalam hal ini yaitu wisatawan Indonesia yang berwisata ke Vietnam. Penghitungan sampel dengan menggunakan rumus Slovin, berdasarkan perhitungan penelitian ini dilakukan dengan menyebarkan kuesioner terhadap 100 orang responden yaitu wisatawan Indonesia yang pernah berwisata ke Vietnam. Penyebaran kuesioner dilakukan melalui platform google form secara online. Teknik analisis data dengan deskriptif kuantitatif, motivasi wisatawan diukur dengan Skala Likert, sementara kepuasan wisatawan diukur dengan mengukur indeks kepuasannya.

\section{HASIL DAN PEMBAHASAN Karakteristik Wisatawan}

Berdasarkan hasil kuesioner yang disebarkan kepada 100 orang responden wisatawan Indonesia yang pernah berwisata ke Vietnam, terdapat karakteristik yang ditinjau berdasarkan dua sub variabel, yaitu tourist descriptor dan trip descriptor. Berdasarkan sub variabel tourist descriptor, sebagian besar wisatawan yang berwisata ke Vietnam merupakan wisatawan Indoenesia yang berasal dari Provinsi Bali yaitu sebanyak 39 orang (39\%), sementara itu ditinjau berdasarkan status pernikahan, didominasi oleh wisatawan yang belum menikah yakni sebanyak 67 orang (67\%), ditinjau berdasarkan jenis kelamin sebagian besar wisatawan berjenis kelamin perempuan sebanyak 60 orang $(60 \%)$, ditinjau berdasarkan tingkat pendidikan sebagian besar mempunyai tingkat pendidikan Strata 1 dengan persentase sebesar 49\%. Karakteristik wisatawan berdasarkan usia, sebagian besar berusia 21-30 Tahun yaitu sebanyak 52 orang (52\%). Ditinjau berdasarkan pekerjaan, sebanyak 46 orang (46\%) bekerja sebagai pegawai swasta.

Karakteristik wisatawan berdasarkan sub variabel trip descriptor, sebagian besar wisatawan melakukan perjalanan di Vietnam selama 3-6 Hari yaitu sebanyak 48 orang (48\%). Ditinjau berdasarkan jenis akomodasi, sebagian besar wisatawan tinggal di Hotel yaitu sebanyak 62 orang (62\%). Ditinjau berdasarkan jenis transportasi, sebagian besar (44\%) wisatawan Indonesia menggunakan transportasi bus selama berwisata di Vietnam.
Sementara itu, ditinjau berdasarkan pengorganisasian perjalanan sebagian besar mengorganisasikan perjalanan sendiri yaitu sebanyak 41 orang (41\%). Ditinjau berdasarkan besar pengeluaran, sebagian besar $(30 \%)$ wisatawan menghabiskan dana 1-3 Juta selama berwisata di Vietnam. Ditinjau berdasarkan jumlah kunjungan, sebagian besar wisatawan Indonesia baru pertama kali berkunjung yaitu sebanyak 74 orang $(74 \%)$. Berdasarkan sumber informasi,, sebagian besar (61\%) wisatawan mendapatkan informasi mengenai Vietnam dari sumber internet.

\section{Motivasi Wisatawan}

Motivasi wisatawan dibagi menjadi empat jenis motivasi, antara lain : motivasi fisik (physical motivation), motivasi budaya (cultural motivation), motivasi interpersonal (interpersonal motivation), dan motivasi status sosial (status and prestige motivation). Berdasarkan hasil penyebaran kuesioner terhadap 100 responden, motivasi wisatawan yang berwisata ke Vietnam dijabarkan pada Tabel 1.

Tabel 1. Motivasi Wisatawan Indonesia yang Berwisata ke Vietnam

No Indikator $\begin{gathered}\text { Rata- } \\ \text { rata }\end{gathered}$

\begin{tabular}{|c|c|c|c|}
\hline \multicolumn{4}{|c|}{ Physical Motivation } \\
\hline 1 & $\begin{array}{l}\text { Relaksasi dan } \\
\text { bersantai untuk } \\
\text { menghilangkan } \\
\text { penat agar } \\
\text { semangat kembali }\end{array}$ & 4,36 & Sangat Setuju \\
\hline 2 & $\begin{array}{l}\text { Berolah raga guna } \\
\text { mendapatkan } \\
\text { kebugaran fisik }\end{array}$ & 2,53 & Tidak Setuju \\
\hline 3 & $\begin{array}{l}\text { Pemeliharaan } \\
\text { kesehatan dari } \\
\text { suatu ganguan atau } \\
\text { penyakit }\end{array}$ & 2,01 & Tidak Setuju \\
\hline & $\begin{array}{l}\text {-rata Skor Physical } \\
\text { Motivation }\end{array}$ & 2,97 & Cukup Setuju \\
\hline \multicolumn{4}{|c|}{ Cultural Motivation } \\
\hline 1 & $\begin{array}{l}\text { Melihat dan } \\
\text { mengetahui } \\
\text { kebudayaan yang } \\
\text { ada di Vietnam }\end{array}$ & 4,53 & Sangat Setuju \\
\hline 2 & $\begin{array}{l}\text { Mengetahui adat } \\
\text { dan tradisi di } \\
\text { Vietnam }\end{array}$ & 4,44 & Sangat Setuju \\
\hline 3 & $\begin{array}{l}\text { Mengetahui } \\
\text { kesenian dan } \\
\text { peninggalan }\end{array}$ & 4,37 & Sangat Setuju \\
\hline
\end{tabular}




\begin{tabular}{|c|c|c|c|}
\hline \multicolumn{4}{|c|}{$\begin{array}{l}\text { sejarah yang ada di } \\
\text { Vietnam }\end{array}$} \\
\hline & $\begin{array}{l}\text {-rata Skor Cultural } \\
\text { Motivation }\end{array}$ & 4,45 & Sangat Setuju \\
\hline \multicolumn{4}{|c|}{ Interpersonal Motivation } \\
\hline 1 & $\begin{array}{l}\text { Mengunjungi } \\
\text { teman dan } \\
\text { keluarga yang } \\
\text { berada di Vietnam }\end{array}$ & 1,99 & Tidak Setuju \\
\hline 2 & $\begin{array}{l}\text { Menemui mitra } \\
\text { kerja/bisnis di } \\
\text { Vietnam }\end{array}$ & 2,24 & Tidak Setuju \\
\hline & $\begin{array}{l}\text { Rata-rata Skor } \\
\text { personal Motivation }\end{array}$ & 2,12 & Tidak Setuju \\
\hline \multicolumn{4}{|c|}{ Status and Prestige Motivation } \\
\hline 1 & $\begin{array}{l}\text { Memperlihatkan } \\
\text { kepada orang lain } \\
\text { bahwa sedang } \\
\text { berlibur ke luar } \\
\text { negeri }\end{array}$ & 3,1 & Cukup Setuju \\
\hline 2 & $\begin{array}{l}\text { Tuntutan bisnis, } \\
\text { dinas, pendidikan, } \\
\text { profesi, hobi, dan } \\
\text { lain-lain }\end{array}$ & 3,06 & Cukup Setuju \\
\hline 3 & $\begin{array}{l}\text { Mendapatkan } \\
\text { gengsi/pengakuan } \\
\text { dari orang orang } \\
\text { sekitar atau } \\
\text { lingkungan }\end{array}$ & 2,22 & Tidak Setuju \\
\hline & $\begin{array}{l}\text { rata Skor Status and } \\
\text { estige Motivation }\end{array}$ & 2,79 & Cukup Setuju \\
\hline
\end{tabular}

Sumber : Hasil Penelitian, 2020.

Berdasarkan Tabel 1, dari keempat sub variabel tersebut, variabel physical motivation memiliki tiga indikator, dengan nilai rata-rata 2,97. Hasil tersebut menunjukkan bahwa, physical motivation tidak sepenuhnya mendorong wisatawan Indonesia berwisata ke Vietnam. Sementara, sub variabel kedua yakni cultural motivation, sub variabel ini memiliki tiga indikator, dengan nilai rata-rata 4,45 hal ini menunjukkan bahwa, cultural motivation merupakan salah satu motivasi yang mendorong wisatawan Indonesia berwisata ke Vietnam. Sub variabel ketiga, yakni interpersonal motivation, yang terdiri dari dua indikator dengan nilai rata-rata 2,12. Nilai ini tergolong rendah, hal ini berarti interpersonal motivation tidak mendorong wisatawan Indonesia berwisata ke Vietnam. Sementara itu, sub variabel keempat yakni status and prestige motivation, yang terdiri dari tiga indikator dengan nilai rata-rata sebesar 2,79. Nilai ini berarti status and prestige motivation tidak sepenuhnya mendorong wisatawan Indonesia berkunjung ke Vietnam.
Jika ditinjau berdasarkan tiap indikator, indikator yang memiliki nilai paling tinggi, yakni melihat dan mengetahui kebudayaan yang ada di Vietnam. Sementara, indikator yang memiliki nilai paling tinggi kedua yakni mengetahui adat dan tradisi yang ada di Vietnam. Indikator dengan nilai tertinggi ketiga yakni mengetahui kesenian dan peninggalan sejarah yang ada di Vietnam. Ketiga indikator tersebut berasal dari sub variabel cultural motivation, hal ini berarti wisatawan Indonesia berkunjung ke Vietnam, didorong oleh motivasi untuk melihat budaya, adat, tradisi, seni dan peninggalan sejarah yang ada di Vietnam. Motivasi budaya tersebut diperkuat dengan adanya empat tempat wisata budaya yang paling disukai responden dalam penelitian ini. Tempat wisata budaya pertama yaitu Ho Chi Minh, khususnya di kota Hue. Dimana pada lokasi ini terdapat kegiatan yang menarik dan menghibur seperti pertunjukan musik dan pertunjukan menari. Tempat wisata budaya kedua yaitu Danau Hoan Kiem yang merupakan danau bersejarah yang ada di Vietnam. Hoan Kiem berarti pedang yang dikembalikan. Dahulu terdapat kura-kura sakti yang menghuni danau tersebut dan memberikan sebuah pedang Thuan Thien kepada kaisar sebagai senjata untuk melawan penjajahan China dan mengusirnya dari Vietnam. Setelah terbebas dari China, kaisar mengembalikan pedang tersebut kepada kura-kura sakti di danau tersebut. Tempat ketiga yaitu kota wisata Hoi An. Pada tempat ini terdapat pertunjukan teater tradisional yang dapat ditonton secara gratis. Kota Hoi An pada masa lampau merupakan kota pelabuhan dagang yang dihuni oleh para pedagang dari Tiongkok, Jepang dan Vietnam. Perpaduan budaya ketiga bangsa ini melahirkan banyak keunikan yang salah satunya berupa tarian dan musik tradisional yang masih lestari hingga saat ini.

Tingginya nilai motivasi budaya ini juga sesuai dengan penelitian yang dilakukan oleh Sagala (2017). Dalam penelitian tersebut, motivasi budaya juga mendapatkan nilai tertinggi. Sementara itu, indikator yang memiliki nilai paling rendah yaitu mengunjungi teman dan keluarga yang berada di Vietnam. Indikator ini hanya memperoleh nilai rata-rata 1,99. Hasil ini sesuai dengan karakteristik wisatawan Indonesia yang sebagian besar first timer dengan persentase $74 \%$. Oleh karena itu, 
Vietnam menjadi tempat wisata yang tidak pernah dikunjungi sebelumnya dan belum mempunyai relasi atau teman serta keluarga yang berada di Vietnam.

\section{Kepuasan Wisatawan}

Kepuasan wisatawan dilihat dari empat komponen pariwisata (4A) yang terdiri atas atraksi wisata (attraction), fasilitas (amenities), aksesibilitas (accessibility), serta pelayanan tambahan (ancillary). Berdasarkan hasil penyebaran kuesioner terhadap 100 orang responden, kepuasan wisatawan Indonesia yang berwisata ke Vietnam pada Tabel 2.

Tabel 2. Kepuasan Wisatawan Indonesia yang Berwisata ke Vietnam

\begin{tabular}{|c|c|c|c|c|}
\hline No & Pernyataan & $\begin{array}{l}\text { Skor } \\
\text { Total }\end{array}$ & $\begin{array}{c}\text { Indeks } \\
\text { Kepuasan }\end{array}$ & Interpretasi \\
\hline \multicolumn{5}{|c|}{ Attraction } \\
\hline 1 & $\begin{array}{l}\text { Vietnam } \\
\text { memiliki } \\
\text { atraksi alam } \\
\text { yang baik dan } \\
\text { menarik }\end{array}$ & 444 & $88,8 \%$ & $\begin{array}{l}\text { Sangat } \\
\text { Puas }\end{array}$ \\
\hline 2 & $\begin{array}{l}\text { Vietnam } \\
\text { memiliki } \\
\text { atraksi wisata } \\
\text { Budaya yang } \\
\text { baik dan } \\
\text { menarik }\end{array}$ & 437 & $87,4 \%$ & $\begin{array}{l}\text { Sangat } \\
\text { Puas }\end{array}$ \\
\hline 3 & $\begin{array}{l}\text { Atraksi } \\
\text { Wisata di } \\
\text { Vietnam } \\
\text { memiliki ciri } \\
\text { khas }\end{array}$ & 426 & $85,2 \%$ & $\begin{array}{l}\text { Sangat } \\
\text { Puas }\end{array}$ \\
\hline & $\begin{array}{l}\text { Total Skor } \\
\text { Attraction }\end{array}$ & 1307 & $87,1 \%$ & $\begin{array}{l}\text { Sangat } \\
\text { Puas }\end{array}$ \\
\hline \multicolumn{5}{|c|}{ Amenities } \\
\hline 1 & $\begin{array}{l}\text { Pelayanan } \\
\text { pada } \\
\text { penginapan } \\
\text { atau hotel } \\
\text { yang } \\
\text { ditempati } \\
\text { selama } \\
\text { berwisata di } \\
\text { Vietnam }\end{array}$ & 421 & $84,2 \%$ & $\begin{array}{l}\text { Sangat } \\
\text { Puas }\end{array}$ \\
\hline 2 & $\begin{array}{l}\text { Menu dan } \\
\text { makanan yang } \\
\text { ada di } \\
\text { restaurant } \\
\text { atau rumah } \\
\text { makan di } \\
\text { Vietnam }\end{array}$ & 412 & $82,4 \%$ & $\begin{array}{c}\text { Sangat } \\
\text { Puas }\end{array}$ \\
\hline 3 & $\begin{array}{l}\text { Tersedianya } \\
\text { tempat ibadah } \\
\text { selama } \\
\text { berwisata }\end{array}$ & 331 & $66,2 \%$ & Puas \\
\hline
\end{tabular}

\begin{tabular}{|c|c|c|c|c|}
\hline 4 & $\begin{array}{l}\text { Kemudahan } \\
\text { mendapatkan } \\
\text { air dan listrik } \\
\text { di tiap tiap } \\
\text { daya tarik } \\
\text { wisata }\end{array}$ & 413 & $82,6 \%$ & $\begin{array}{l}\text { Sangat } \\
\text { Puas }\end{array}$ \\
\hline & $\begin{array}{l}\text { Total Skor } \\
\text { Amenities }\end{array}$ & 1577 & $78,9 \%$ & Puas \\
\hline \multicolumn{5}{|c|}{ Accessibility } \\
\hline 1 & $\begin{array}{l}\text { Terdapat bus } \\
\text { pariwisata }\end{array}$ & 412 & $82,4 \%$ & $\begin{array}{c}\text { Sangat } \\
\text { Puas }\end{array}$ \\
\hline 2 & $\begin{array}{l}\text { Pelayanan } \\
\text { penyewaan } \\
\text { sepeda motor } \\
\text { atau mobil }\end{array}$ & 398 & $79,6 \%$ & Puas \\
\hline 3 & $\begin{array}{l}\text { Terdapat } \\
\text { transportasi } \\
\text { umum seperti } \\
\text { bus dan kereta } \\
\text { api yang dapat } \\
\text { mengakses } \\
\text { Daya Tarik } \\
\text { Wisata }\end{array}$ & 393 & $78,6 \%$ & Puas \\
\hline 4 & $\begin{array}{l}\text { Lancarnya } \\
\text { lalu lintas di } \\
\text { Vietnam }\end{array}$ & 359 & $71,8 \%$ & Puas \\
\hline & $\begin{array}{l}\text { Total Skor } \\
\text { Accessibility }\end{array}$ & 1562 & $78,1 \%$ & Puas \\
\hline \multicolumn{5}{|c|}{ Ancillary } \\
\hline 1 & $\begin{array}{l}\text { Terdapat } \\
\text { tourist } \\
\text { information di } \\
\text { Daya Tarik } \\
\text { Wisata }\end{array}$ & 396 & $79,2 \%$ & Puas \\
\hline 2 & $\begin{array}{l}\text { Keamanan } \\
\text { yang ada di } \\
\text { Daya Tarik } \\
\text { Wisata } \\
\text { sehingga } \\
\text { meminimalisir } \\
\text { tindak } \\
\text { kriminal }\end{array}$ & 400 & $80 \%$ & Puas \\
\hline 3 & $\begin{array}{l}\text { Terdapat } \\
\text { Kedutaan } \\
\text { Besar } \\
\text { Republik } \\
\text { Indonesia di } \\
\text { Vietnam yang } \\
\text { menjamin } \\
\text { wisatawan } \\
\text { Indonesia } \\
\text { selama berada } \\
\text { di Vietnam }\end{array}$ & 406 & $81,2 \%$ & $\begin{array}{c}\text { Sangat } \\
\text { Puas }\end{array}$ \\
\hline & al Skor Ancillary & 1202 & $80,1 \%$ & Puas \\
\hline & $\begin{array}{l}\text { or Total Tingkat } \\
\text { Kepuasan } \\
\text { Wisatawan }\end{array}$ & 5648 & $80,7 \%$ & Puas \\
\hline
\end{tabular}

Sumber : Hasil Penelitian, 2020.

Berdasarkan Tabel 2, dapat dilihat bahwa sub variabel atraksi wisata memiliki tiga indikator dengan nilai tingkat kepuasan sebesar $87,1 \%$. Nilai tersebut berarti wisatawan 
Indonesia yang berkunjung ke Vietnam sangat puas dengan atraksi wisata yang ada di Vietnam. Sub variabel kedua, yakni fasilitas dengan empat indicator dan memilki nilai tingkat kepuasan sebesar $78,9 \%$ yang berarti wisatawan Indonesia puas terhadap fasilitas yang ada di Vietnam. Sementara itu, sub variabel ketiga yaitu aksesibilitas dengan empat indikator yang memiliki nilai tingkat kepuasan sebesar $71,8 \%$. Nilai ini berarti wisatawan Indonesia puas terhadap aksesibilitas atau kemudahan mengakses tempat wisata di Vietnam. Sub variabel keempat, yakni pelayanan tambahan yang memiliki tiga indikator dengan nilai tingkat kepuasan sebesar $80,1 \%$. Nilai tersebut berarti wisatawan Indonesia puas terhadap pelayanan tambahan yang ada di Vietnam.

Ditinjau dari tiap indikator, indikator yang memiliki nilai tertinggi yakni Vietnam memiliki atraksi alam yang baik dan menarik dengan indeks kepuasan sebesar $88,8 \%$. Nilai ini berarti wisatawan Indonesia sangat puas dengan wisata alam yang ada di Vietnam. Vietnam memang memiliki berbagai atraksi alam yang menarik minat wisatawan. Atraksi wisata alam yang paling terkenal di Vietnam yaitu Ha Long Bay. Ha Long Bay dengan panorama alam yang sangat indah ini memiliki luas sekitar $1.533 \mathrm{~km}$ persegi dan kawasan legendaris itu ialah kesatuan dari 2.000 pulaupulau kecil. Pulau-pulau tersebut kebanyakan merupakan pulau batuan kapur. Ha Long Bay juga menjadi rumah untuk 14 spesies flora endemik serta 60 spesies fauna endemik. Sehingga UNESCO menobatkan kawasan teluk ini menjadi salah satu tempat World Heritage Site. Hal ini diperkuat juga dengan hasil penelitian bahwa $39 \%$ responden memilih $\mathrm{Ha}$ Long Bay sebagai tempat wisata yang paling disukai di Vietnam. Sementara itu, indikator yang memiliki nilai terendah yakni tersedianya tempat ibadah selama berwisata dengan indeks kepuasan sebesar $66,2 \%$. Nilai ini memiliki arti wisatawan Indonesia cukup puas terhadap tersedianya tempat ibadah selama berwisata di Vietnam. Rendahnya nilai indikator ini dibandingkan indikator lainnya karena Vietnam merupakan negara yang memiliki mayoritas penduduk tidak beragama. Berdasarkan data dari Kedutaan Besar Republik Indonesia di Hanoi (2018), diketahui bahwa mayoritas penduduk Vietnam tidak beragama (70\%).
Sementara, sisanya beragama Buddha (14\%), Katolik (8,4\%), Cao Dai (3,4\%), Protestan $(2,1 \%)$, Hoa Hao Buddha $(1,8 \%)$, dan Islam $(0,1 \%)$.

Jika ditinjau secara keseluruhan, skor total tingkat kepuasan wisatawan Indonesia yang berwisata ke Vietnam memiliki nilai tingkat kepuasan sebesar $80,7 \%$. Nilai ini berarti wisatawan Indonesia yang berkunjung ke Vietnam puas selama berkunjung di Vietnam dilihat dari empat komponen utama pariwisata yakni attraction, amenities, accessibility, dan ancillary yang ada di Vietnam. Hasil ini sesuai dengan hasil penelitian yang dilakukan oleh Pawitra (2003) bahwa wisatawan Indonesia yang berkunjung ke Singapura merasa puas terhadap attraction, amenities, accessibility dan ancillary yang ada di Singapura. Hasil penelitian ini juga serupa dengan penelitian yang dilakukan oleh Truong (2005) yang menunjukkan bahwa wisatawan Australia yang berkunjung ke Vietnam ditinjau dari komponen pariwisata 4A, merasa puas terhadap attraction, accessibility, amenities yang ada di Vietnam.

\section{SIMPULAN DAN SARAN \\ Simpulan}

Berdasarkan hasil analisis data dan pembahasan yang telah diuraikan mengenai karakteristik, motivasi dan kepuasan wisatawan Indonesia yang berwisata ke Vietnam, maka dapat diambil simpulan bahwa:

1. Karakteristik wisatawan Indonesia yang berwisata ke Vietnam, jika ditinjau dari tourist descriptor sebagian besar berasal dari Bali, belum menikah, berjenis kelamin perempuan, dan memiliki tingkat pendidikan Sarjana (S1), berusia diantara 21-30 tahun, dominan bekerja sebagai karyawan swasta, kemudian lama menginap di Vietnam berkisar antara 3-6 hari, menginap di hotel, menggunakan transportasi bus, mengorganisasikan perjalanannya sendiri, memiliki besar pengeluaran selama di Vietnam sejumlah Rp. 1.000.000-3.000.000, dan merupakan wisatawan first timer serta menggunakan internet sebagai sumber informasi tentang Vietnam.

2. Motivasi yang paling mempengaruhi wisatawan Indonesia yang berwisata ke Vietnam yaitu cultural motivation dengan nilai rata-rata 4,45 (sangat setuju). Ditinjau 
berdasarkan tiap indikator, maka indikator melihat dan mengetahui kebudayaan yang ada di Vietnam merupakan indikator yang paling memotivasi wisatawan Indonesia berwisata ke Vietnam, indikator ini memiliki nilai rata-rata 4,53.

3. Kepuasan Wisatawan selama berwisata di Vietnam dikaji berdasarkan empat komponen utama pariwisata (4A) yang terdiri dari attraction, amenities, accessibility, dan ancillary. Dari keempat komponen utama pariwisata tersebut, komponen attraction mempunyai nilai tingkat kepuasan tertinggi tertinggi yaitu $87,1 \%$ (Sangat Puas). Jika dilihat berdasarkan tiap indikator, indikator Vietnam memiliki wisata alam yang baik dan menarik memiliki tingkat kepuasan yang tertinggi dengan nilai $88,8 \%$ (Sangat Puas). Sementara itu, secara keseluruhan tingkat kepuasan wisatawan Indonesia yang berwisata ke Vietnam memiliki nilai sebesar 80,7\% (Puas). Hasil tersebut berarti secara keseluruhan wisatawan Indonesia yang berwisata ke Vietnam puas terhadap attraction (atraksi wisata), amenities (fasilitas), accessibility (aksesibilitas), dan ancillary (pelayanan tambahan) yang ada di Vietnam.

\section{Saran}

Berdasarkan hasil pembahasan dan simpulan dari penelitian ini, adapun saran yang dapat direkomendasikan adalah sebagai berikut:

1. Berdasarkan hasil penelitian mengenai motivasi wisatawan Indonesia yang berwisata ke Vietnam diketahui bahwa motivasi yang memiliki nilai rata-rata paling tinggi yaitu cultural motivation. Maka dapat disarankan kepada pemerintah dan pengusaha wisata untuk lebih menonjolkan atraksi wisata budaya yang ada di Vietnam guna meningkatkan kunjungan wisatawan Indonesia berkunjung ke Vietnam.

2. Berdasarkan hasil penelitian mengenai kepuasan wisatawan Indonesia yang berwisata ke Vietnam diketahui bahwa tingkat kepuasan yang paling rendah yaitu pada indikator tersedianya tempat ibadah selama berwisata, maka dari itu direkomendasikan kepada biro perjalanan wisata yang menangani wisatawan Indonesia yang akan berwisata ke Vietnam, untuk memberikan informasi yang jelas mengenai kondisi tersebut, dan pihak biro perjalanan wisata disarankan, untuk menyediakan ruangan sementara, khusus untuk ibadah pada saat wisatawan melakukan perjalanan wisata.

3. Berdasarkan hasil karakteristik, sebagian besar responden mengorganisasikan perjalanannya sendiri, maka dari itu disarankan kepada biro perjalanan wisata di Indonesia untuk merancang dan menjual paket wisata ke Vietnam, karena masih minimnya biro perjalanan yang menangani wisatawan Indonesia berkunjung ke Vietnam.

4. Berdasarkan hasil penelitian mengenai karakteristik wisatawan Indonesia yang berwisata ke Vietnam ditinjau dari besar pengeluaran, diketahui bahwa wisatawan Indonesia sebagian besar menghabiskan 13 Juta rupiah selama berwisata di Vietnam. Maka dari itu dapat disarankan untuk penelitian selanjutnya agar meneliti pola pengeluaran wisatawan Indonesia yang berwisata ke Vietnam. 


\section{Kepustakaan}

Badan Pusat Statistik. 2019. Data Wisatawan Mancanegara. (Online). (https://www.bps.go.id/pencarian.html?s earching=wisatawan $+\mathrm{ke}+$ mancanegara \&yt2=Cari, diakses pada 15 oktober 2019).

Data, CEIC. 2019. Kunjungan Wisatawan Indonesia ke Vietnam. (Online). (https://www.ceicdata.com/datapage/id/ search?search_query=vietnam, diakses pada 10 oktober 2019).

Emmanuel, Majekodunmi. 2015. The Influence of Workplace Environment on Workers' Welfare, Performance and Productivity. The African S ymposium, 12 (1).

Government of Tourism Vietnam. 2019. International Visitors Statistic. (Online). (http://vietnamtourism.gov.vn/english/in dex.php/cat/1501/1, diakses pada 10 oktober 2019).

Macintosh, Gerrard. 2002. Customer orientation, relationship quality, andrelational benefits to the firm. Journal of Services Marketing, 21/3 150-159.

Pawitra, Theresia A. 2003. Tourist Satisfaction in Singapore- A Perspective from Indonesian Tourist. Managing Service Quality Journal Vol. 13, Number 5, 399441.

Pitana, IG. Dan Gayatri, IG. 2005. Sosiologi Pariwisata. Yogyakarta : Penerbit ANDI.

Sagala, Patricia L. 2017. Motivasi Wisatawan Berkunjung ke Daerah Tujuan Wisata Danau Toba Sumatera Utara. JOM FISIP Vol. 4 No.1.

Seaton, A.V. And M.M. Bennett. 1996. The Marketing of Tourism Product : Concepts, Issues, and Cases. London : International Thomson Business Press.

Truong, Thuy-Huong. 2005. Acessing Holiday Satisfaction of Australian Travellers in Vietnam: An Application of the HOLSAT Model. Asia Pasific Journal of Tourism Reseach, Vol. 10, Number 3. 